\title{
WHAT DOES THE LONG-LIVED NESTOR'S CUP HOLD IN STORE? REMARKS ON THE RECEPTION OF THE THEME IN ICONOGRAPHY AND LITERATURE
}

\begin{abstract}
Milewska-Waźbińska Barbara, What Does the Long-lived Nestor's Cup Hold in Store? Remarks on the Reception of the Theme in Iconography and Literature (Co kryje puchar dugowiecznego Nestora? Uwagi o recepcji motywu w ikonografii i literaturze).

The paper studies selected aspects of the reception of Homeric theme of Nestor's cup in the early modern times, both in emblematics and in literary worksThe longevity of king of Pylos and his oratorical skills were often alluded to in the Greek and Latin literature. As it turns out, the interpretation of the cup's adornments included in Athenaeus' Banquet of the Learned was widely discussed in the early modern times. This interpretation contributed both to the study of emblematics and literary works. The Homeric theme left its indelible mark also on the Old Polish literature, as in the funeral oration in honor of Bishop of Cracow Jakub Zadzik entitled Nestor Sarmaticus written by Jan Cynerski-Rachtamowicz.
\end{abstract}

Keywords: Nestor's cup; Andreas Alciatus; Jakub Zadzik; Jan Cynerski-Rachtamowicz.

One of the most conspicuous Homeric characters immortalized in the literary and cultural tradition is Nestor. It is impossible to discuss all aspects of the impact of this character on the European culture within the space of a single article. With this in mind, my purpose is to indicate one of the paths that early modern authors followed.

It is worth reminding that in the first Book of Illiad, this old man takes the floor after Agamemnon and Achilles' shouting match. King of Pylos asserts himself as an unchallenged orator. Known for his unique quality of defusing tensions, his speech is seething with comforting words, which are deemed sweeter than honey. ${ }^{1}$ The gift of speech bestowed upon him serves not only to appease people's wrath, but also to pass life experience on to the young. Whilst spinning the yarn about the olden days of Argives' glorious deeds, Nestor seeks both to pass the ancestral heroic traditions and to spur the young on to fight. ${ }^{2}$ His ability to speak allows scholars to see the ruler of Pylos as an archetype of

${ }^{1}$ Hom. Il. I 249.

${ }^{2}$ Hom. Il. I 123-174. 
the traditional oral poet, ${ }^{3}$ which is made evident in the rhetorical style of his speeches. ${ }^{4}$

Homer does not fail to mention Nestor's longevity. According to his account, Nestor ruled over three generations of the subjects of Pylos. Despite his old age and physical decline, Nestor is prepared to fight in Troy. His infirmity is held against him by Diomed, ${ }^{5}$ who, however, admires the old man's vigilance, after the latter wakes him up for a debate. ${ }^{6}$

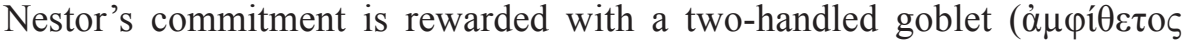
$\varphi(\alpha \dot{\lambda} \lambda \eta)^{7}$ conferred by Achilles at the closing of the games dedicated to Patroclus. However, the king of Pylos fails to participate in the competition in person as a consequence of his old age and frailty. Nestor says:

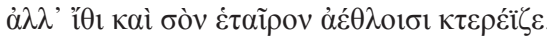

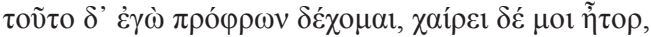

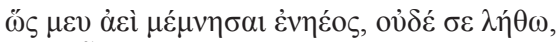

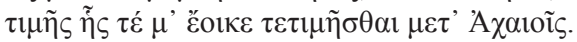

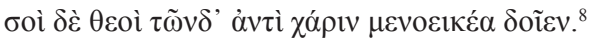

For this gift, I receive it with gladness, and my heart rejoiceth that thou rememberest me, thy friend, neither am I forgotten of thee, and the honour wherewith it beseemeth that I be honoured among the Achaeans. And to thee may the gods in requital thereof grant grace to satisfy thy heart. ${ }^{9}$

This poignant scene serves to exemplify mutual respect between the old and young generations to this day.

As it is commonly known, Nestor was in the possession of another finelooking cup ( $\delta \varepsilon \dot{\varepsilon} \pi \varsigma \varsigma \varepsilon \rho \iota \kappa \alpha \lambda \lambda \varepsilon \dot{\varepsilon} \varsigma)$ described in depth in the $11^{\text {th }}$ book of Illiad:

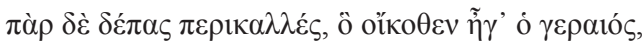

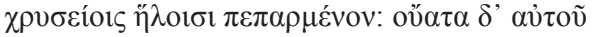

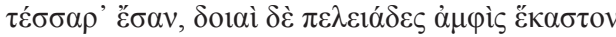

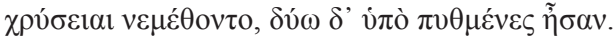

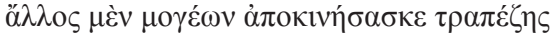

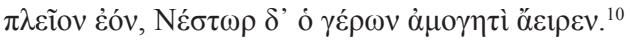

and beside them a beauteous cup, that the old man had brought from home, studded with bosses of gold; four were the handles thereof, and about each twain doves were feeding, while

\footnotetext{
${ }^{3}$ Dickson 1995.

${ }^{4}$ Knudsen 2014, 15-88.

${ }^{5}$ Hom.Il. VIII 101-104.

${ }^{6}$ Hom. Il. X 164-167.

${ }^{7}$ Hom. Il. XXIII 616.

${ }^{8}$ Hom. Il. XXIII 646-650.

${ }^{9}$ Homer 1988, 542-543.

${ }^{10}$ Hom. Il. XI 632-637.
} 
below were two supports. Another man could scarce have availed to lift that cup from the table, when it was full, but old Nestor would raise it right easily. ${ }^{11}$

It has been confirmed in modern times that the cup and goblet were not merely a figment of the poet's imagination. In the second half of the $19^{\text {th }}$ century Heinrich Schliemann found a golden goblet dating back to the $16^{\text {th }}$ century BC in Mycenae, named after Nestor due to its adornment. Nearly a century later a clay drinking vessel dating back to the $8^{\text {th }}$ century BC was found in the Greek settlement at Pithekoussai Island in The Gulf of Naples bearing the following inscription: "I am the cup of Nestor, easy to drink from. Whoever drinks from this cup, the desire of fair-garlanded Aphrodite will seize him at once." ${ }^{\prime 2}$ As argued by Marek Węcowski, ${ }^{13}$ this epigram testifies to the sophistication of the literary culture of the Ancient Greece.

Given its sympothic function, it should not come as surprise that Nestor's cup had its entry in Athenaeus' compendium Deipnosophistae (The Banquet of the Learned). Book 10 mentions that Nestor was partial to wine, and in Book 12, in the passage describing tableware, the author alludes to the quoted scene from Book 11 of Illiad. Quoting Asclepiades of Myrlea, Athenaeus ventures to discern the pattern of the universe in the cup's adornments. He argues that the pattern could be identified in the round shape of the vessel as well as its ornamentation: the cup was gold-studded like stars. The author of Deipnosophistae goes on to argue that the cup was festooned with the Pleiades star cluster, rather than doves. In Greek both words sound similarly: "pleiades" and "peleiades."

Nestor's longevity and oratorical skills were often alluded to in the Latin literature. In Fasti, Ovid portrays a festivity wherein the number of toasts the guests drank was to match the number of years Nestor lived, which was to assure their longevity:

sole tamen vinoque calent annosque precantur, quot sumant cyathos, ad numerumque bibunt.

invenies illic, qui Nestoris ebibat annos, quae sit per calices facta Sibylla suos. ${ }^{14}$

But they grow warm with sun and wine, and they pray for as many years as they take cups, and they count the cups they drink. There shall you find a man who drains as many goblets as Nestor numbered years, and a woman who would live to the Sibyl's age if cups could work the charm. ${ }^{15}$

\footnotetext{
${ }^{11}$ Homer 1988, 526-529.

${ }^{12}$ Fantuzzi and Hunter 2004, 286.

${ }^{13}$ Węcowski 2011, 119-129.

${ }^{14}$ Ov. Fasti III 531-534.

${ }^{15}$ Ovid 1959, 159-161.
} 
The poet seems to allude to Nestor's two distinguishing characteristics: drinking and longevity.

Another reference to Nestor's cup described by Homer appears in one of Martial's epigrams in which the garrulous old man claims that a dove engraved on one of the vases was burnished by none else than Nestor himself:

hi duo longaevo censentur Nestore fundi:

pollice de Pylio trita columba nitet. ${ }^{16}$

Those two goblets are valuable because of aged Nestor: the dove is burnished by the rubbing of the Pylian thumb. ${ }^{17}$

As it turns out, the reflections included in Athenaeus' Deipnosophistae were widely discussed in the early modern era. The work's editio princeps was published in Venice at Aldus Manutius' printing office in 1514, and its second

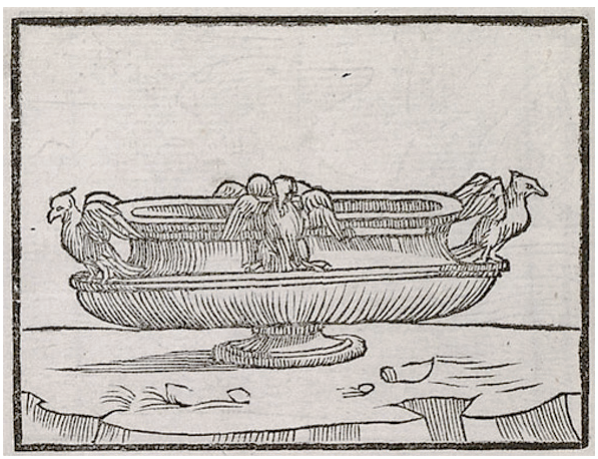

Figure 1. The shape of Nestor's cup a fragment, according to Andreae Alciati Emblematum libellus nuper in lucem editus, Venetiis: Aldus 1546, fol. B1v. edition in 1535 in Basil. Another interesting link, as regards the tradition of Nestor's cup, is emblematics. In a new edition of Alciatus' emblem books published in 1546 in Venice by Aldus' son, including 86 hitherto unpublished epigrams, on page 9 verso the image of Nestor's cup is shown. The plate illustrates a wide vessel with spread-winged birds on all four sides of the edge, with their backs turned to the edges.

The emblem carries the inscription "Scyphus Nestoris", and under the picture there is the following epigram:

Nestoreum geminis cratera hunc accipe fundis,

Quod gravis argenti massa profudit opus.

Claviculi ex auro, stant circum quatuor ansae:

Unamquamque super fulva columba sedet.

Solus eum potuit longaevus tollere Nestor.

Maeonide, doceas quid sibi Musa velit?

Est coelum, scyphus ipse: colorque argenteus illi,

Aurea sunt coeli sidera claviculi.

Pleiadas esse putant, quas dixerit ille columbas:

Umbilici gemini magna minorque fera est.

Haec Nestor longo sapiens intelligit usu:

Bella gerunt fortes, callidus astra tenet.

\footnotetext{
${ }^{16}$ Mart. Epigr. VIII 6, 9-10.

${ }^{17}$ Martial 1920, 9.
} 
Take this Nestorean cup with its double bowl, a work of art produced from a mass of weighty silver. Its studs are made of gold, and four handles surround it; on each of these sits a golden dove. Though he was advanced in years, only Nestor could lift it. Maeonian, would you teach us what the Muse meant thereby? The cup itself is the sky, and it has a silvery colour; the studs are the golden stars of heaven. What he called doves are thought to be the Pleiades; and the bear, both the Greater and the Lesser form its twin centres. From long experience, wise Nestor understands these truths: strong men wage wars, a sage man holds the stars.18

If the first part of the epigram describes a vessel carried on the plate, the second part contains obvious references to Athenaeus' interpretation. This testifies to the wide recognition of Deipnosophistae in humanistic circles. The latter had already adopted allegorical the interpretation which the work helped popularize. Athenaeus' work, along with Alciatus' emblem, was referred to by Konrad Gesner in the third book of his Historiae animalium published in $1555 .{ }^{19}$

Notably, the first translation of Athenaeus' work into Latin by Natale de' Conti was published in 1556 in Venice (in folio), Basel, Paris and Lyon (in octavo) at the same time. ${ }^{20}$ However, Jacques Daléchamp's translation, published in Lyon in 1583 resonated more widely in Europe. This edition with a fuller index and marginal notes contains also a shape of Nestor's cup. The Greek original contained Daléchamp's translation into Latin. At the turn of the $16^{\text {th }}$ and $17^{\text {th }}$ century numerous bilingual editions of Athenaeus' work were issued. Isaac Casaubon took pains to correct the Greek text in these editions.

However in the subsequent editions of Alciatus's emblems, including the French and Spanish versions, the quoted epigram was preceded by another plate that depicted Nestor holding the cup. The doves adorning the vessel had their beaks pointed to the edges. Nestor was usually conceived as a bearded old man wearing Greek or Oriental attire.

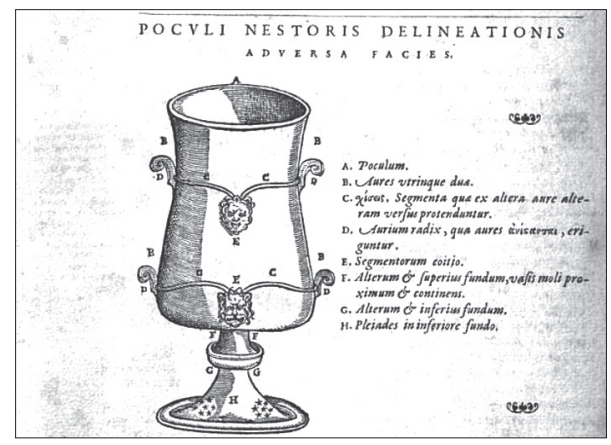

Figure 2. A shape of Nestor's cup a fragment, according to Athenaei ...

Deipnosophistarum libri quindecim in Latinum sermonem versi a Iacobo Dalechampio, Lugduni apud Antonium de Harsy, 1583, p. 364 .

${ }^{18}$ Latin text according to: http://www.mun.ca/alciato/102.html, English text according to: http://www.mun.ca/alciato/e102.html (accessed 13.09.2013).

${ }^{19}$ Gesner 1555, 297.

${ }^{20}$ Bancroft-Marcus 2000, 53. I am grateful to Professor Krystyna Bartol for drawing my attention to this article. 


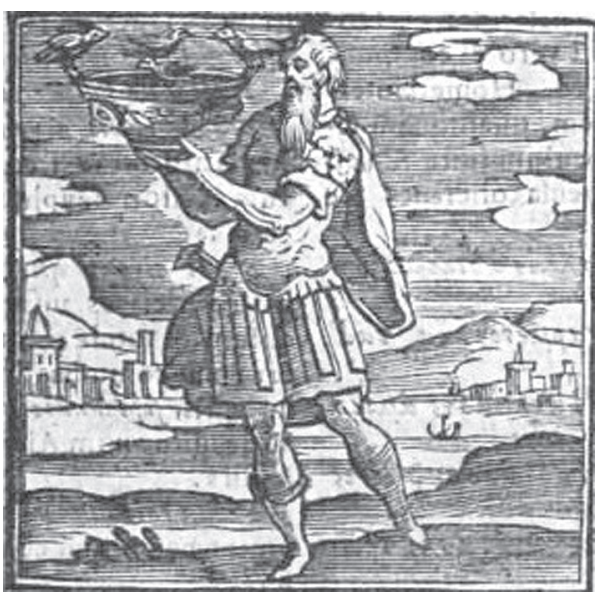

Figure 3. Nestor holding a cup - a fragment, according to Andreae Alciati emblemata, Patavii apud Petrum Paulum Tozzium, 1621, p. 423.
It turns out that both Nestor's cup and his longevity immortalized in Athenaeus' work and Alciatus's emblem left their indelible mark on the Old Polish literature as well. Szymon Okolski in his three-volume Latin heraldic work published in Cracow between 1641 and 1645 entitled Orbis Polonus introduces a genealogy of Polish and Lithuanian noblemen. The historical part of the work is preceded by short rhetorical entries detailing heraldic symbolism. Okolski tries to show a relationship between the coat of arms and virtues of Polish nobility. In describing the Korwin coat of arms he mentions the Age of Nestor: Nestorea aetas.

Okolski claims that Christians do not count years. ${ }^{21}$ If they live virtuously, they achieve a place in heaven for eternity. It is worth noting that Erasmus in his Adagia $^{22}$ considered a similar proverb: Nestorea Senecta.

Another work, a Latin panegyric in commemoration of the late Bishop of Cracow and Chelmno, Great Crown Chancellor Jakub Zadzik was published in Cracow in 1642. Although Jakub Zadzik died, as they say nowadays, in full bloom of his abilities at sixty, ${ }^{23}$ the brochure is titled Nestor Sarmaticus. The brochure was authored by professor of Academy of Cracow Jan Cynerski-Rachtamowicz.

In an inscription dedicated to Jan Tarnowski the author claims that both the Greek hero and the late bishop called Nestor Sarmaticus achieved their due immortality owing to their intermediary agency. The panegyrist opens his funeral valediction with a remark on the deceased's distinguished eloquence, by which he subscribes to the accepted belief that the bishop cultivated the art of verbal persuasion pioneered by Nestor. The panegyric contains quotations that validate Jan Cynerski's argumentation. An extensive passage from book 12 of Institutio Oratoria (chapters 2-7) by Quintilian is found on pages B3vB3r. On page D recto the author quotes an extensive piece from Petro Bembo's work Ad Nicolaum Teupolum. This praise of the eloquence of Guido Ubaldo referred to as Nestor Feretrius (meaning of Montefeltro) can be found in the

\footnotetext{
${ }^{21}$ Okolski 1641, 462.

${ }^{22}$ Erasmus 1998, 93.

${ }^{23}$ Erber 1998, 13.
} 
1611 edition Historia Veneta by the same author. 24

On page $\mathrm{H}$ verso of Cynerski's panegyric there is another noteworthy reference to Nestor. The author is full of admiration for a precious vessel belonging to the hero which nobody but the owner himself is able to lift from the table. Jan Cynerski posits that this can be understood as a symbol of the old man's remarkable and unparalleled eloquence. By referring to Homer, the author of the panegyric goes on to depict the cup using encrypted quotations from Daléchamps' translation of Athenaeus. Another passage from the work, introduced on page $\mathrm{H} 2$ recto and quoted almost in verbatim, opens with the following words: "which Myrleanus in Athenaeus' version in book 11 seriously takes into account."

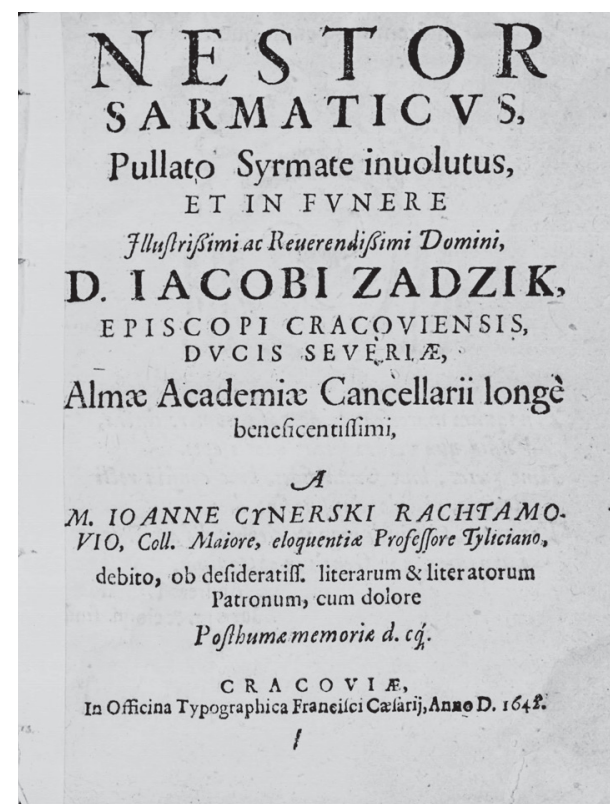

Figure 4. The title page of Nestor Sarmaticus ... a M. Joanne Cynerski Rachtamovio, Cracoviae in officina Francisci Caesarii $1642^{24}$

The next noteworthy fragment

quoted in the panegyric is the text of Alciatus's emblem, who was referred to as iurisperitorum eloquentissimus (the most eloquent of iurists). Jan Cynerski changed only one word in the last verse. Instead of 'callidus' we read: 'Nestor'. The author of the panegyric would probably avoid the ambiguous meaning of the adjective 'callidus' (astute).

Summarizing his own remarks, the author gathers that the virtues of the late bishop Zadzik - referred to as the Sarmatian Nestor - match the symbolic meaning of the cup. The late bishop came to realise that such worldly goods as distinctions or bounties fall prey to the vicissitudes and twists of fate only too easily. He, on the other hand, would always turn his gaze towards heavens, which apparently won him God's favour. With reference to the description of the vessel, Jan Cynerski argues that the late bishop advised that the purity of silver be mirrored in words, simplicity of dove in the heart, the riches of charity reflected in deeds and achievements.

Seeking to expand upon the concept of fundum duplex quoted in the Latin translation of Homer, the panegyrist asserts that the awareness of death and the eternal life constituted a sort of "double foundation" to Jakub Zadzik: "duplex

\footnotetext{
${ }^{24}$ (www.wbc.poznan.pl:48396 - accessed 17.09.2013)
} 
fundum mortis memoria et aeternitas". After all, he would always see heaven and stars flashing before his eyes, as imagined by Athenaeus. The deceased might not have lived as long as the Greek Nestor, but the author of the panegyric declares, much to the readers' cheering, that his life was blessed with glory and that his innumerable accomplishments would remain imprinted on peoples' memory for centuries to come. The brochure is topped by an epitaph imitating the style of stone engravings, that is elogium. Two classical quotations discussing Nestor's gift of speech open the epitaph. The first one from Cicero's Brutus, ${ }^{25}$ and the other from Quintilian's Institutio oratoria. ${ }^{26}$

Jan Cynerski-Rachtamowicz composed his funeral speech with the use of rhetorical and elocutionary devices, which he is purported to have recommended to his students. The title, for example, includes a reference to a well-known ancient hero whose name follows the epithet Sarmaticus. By doing so, the author implied that although the person and events he described were contemporary to his times, he also made references to the ancient tradition. In the speech, composed - to remind - in Latin, as befits the deceased's status and education, the author displays scholarly erudition. Consistent with the dominant literary fashion and aesthetic culture of the period, he brought into play quotations as well as expanded the allegorical interpretation of the mythological character and his vessel in the Christian spirit.

To cap it all, it must be noted that Jan Cynerski-Rachtamowicz tutored the future king of Poland, Jan Sobieski in his school days. In this context, it may be worth mentioning that one of the books found in the impressive collection of the royal library was Athenaeus' Deipnosophistarum libri XV compiled by Isaac Casaubon and published in Lyon in 1612. ${ }^{27}$ Thus, what does the Nestor's cup hold in store? It represents multiple traditions, which played a significant role in the process of the assimilation of the ancient culture in the early modern era. On top of that, the cup's rhetorical potential proved attractive to educated readers.

\section{BIBLIOGRAPHY}

Primary sources

Alciati 1621: Alciati, A. 1621. Emblemata. Patavii: apud Petrum Paulum Tozzium.

Athenaeus 1583: Athenaeus 1583. Athenaei Naucratitae Deipnosophistarum Libri Quindecim in Latinum Sermonem versi a Iacobo Dalechampio. Lugduni: apud Antonium de Harsy.

Cynerski-Rachtamowicz 1642: Cynerski-Rachtamowicz, J. 1642. Nestor Sarmaticus, pullato Syrmate involutus [...] a M. Joanne Cynerski Rachtamovio, Cracoviae: In officina Francisci Caesarii.

\footnotetext{
${ }^{25}$ Cic. Brut. 39-40.

${ }^{26}$ Quint. Inst. XII 10.

${ }^{27}$ Komasara 1982, 136.
} 
Erasmus 1998: Erasmus, D. 1998. Opera omnia Erasmi Roterodami ordinis secundi tomus secundus. Ed. by M. Laetitia van Poll-van de Lisdonk, and M. Cytowska. Amsterdam: Elsevier.

Gesner 1555: Gesner, C. 1555. Conradi Gesneri ...Historiae animalium liber III qui est de Avium natura. Tiguri: apud Christophum Froschoverum.

Homer 1988: Homer. 1988. The Iliad. Vol. II. Transl. by A.T. Murray. London: William Heinemann Ltd.

Martial 1920: Martial. 1920. Epigrams. Vol. II. Transl. by W.C.A. Ker. London: William Heinemann Ltd and New York: G.P. Putnam's Sons.

Okolski 1641: Okolski, Sz. 1641. Orbis Polonus, Splendoribus caeli: Triumphis mundi: Pulchritudine animantium: Decore aquatilium: Naturae excellentia reptilium condecoratus. Vol. I. Cracoviae: Officina Francisci Caesarii.

Ovid 1959: Ovid. 1959. Transl. by J.G. Frazer. London: William Heinemann Ltd.

\section{Secondary sources}

Bancroft-Marcus 2000: Bancroft-Marcus, R. 2000. A Dainty Dish To Set Before a King. Natale De'Conti's Translation of Athenaeus' Deipnosophistae in: Athenaeus and His World: Reading Greek Culture in the Roman Empire. Ed. by D Braund and J. Wilkins. Exeter: University of Exeter Press.

Dickson 1995: Dickson, K. 1955. Nestor: Poetic Memory in Greek Epic. New York: Garland Publishing.

Erber 1998: Erber, Cz. 1998. "Wokół postaci Jakuba Zadzika (1582-1642). Część I. Autorzy utworów panegirycznych.” Kieleckie Studia Bibliologiczne 4, 9-21.

Fantuzzi, Hunter 2004: Fantuzzi, M., R. Hunter. 2004. Tradition and Innovation in Hellenistic Poetry. Cambridge: Cambridge University Press.

Knudsen 2014: Knudsen, R. A. 2014. Homeric Speech and the Origins of Rhetoric. Baltimore: Johns Hopkins University Press.

Komasara 1982: Komasara, I. 1982. Jan III Sobieski miłośnik ksiag, Wrocław: Ossolineum.

Węcowski 2011: Węcowski, M. 2011. Sympozjon, czyli wspólne picie. Początki greckiej biesiady arystokratycznej (IX-VII wiek p.n.e.). Warszawa: Wydawnictwo Naukowe Sub Lupa.

\section{CO KRYJE PUCHAR DŁUGOWIECZNEGO NESTORA? UWAGI O RECEPCJI MOTYWU W IKONOGRAFII I LITERATURZE}

Streszczenie

Artykuł poświęcony jest wybranym aspektom recepcji homeryckiego motywu pucharu należącego do Nestora. W literaturze greckiej i łacińskiej odnaleźć można częste aluzje do długowieczności władcy Pylos i jego umiejętności przemawiania. Okazuje się, że w dobie nowożytnej największy rezonans wywołała interpretacja zdobienia pucharu zawarta w Uczcie mędrców Atenajosa. Interpretacja ta wpłynęła na recepcję motywu w kulturze nowożytnej, zarówno w emblematyce, jak i w literaturze nowołacińskiej. Homerycki motyw pozostawił swój ślad również w staropolskiej tradycji literackiej, między innymi w mowie pogrzebowej ku czci biskupa krakowskiego Jakuba Zadzika zatytułowanej Nestor Sarmaticus autorstwa Jana CynerskiegoRachtamowicza. 